University of Nebraska - Lincoln

DigitalCommons@University of Nebraska - Lincoln

Agronomy \& Horticulture -- Faculty Publications

Agronomy and Horticulture Department

2003

\title{
Forage Yield and Economic Losses Associated with the Brown- Midrib Trait in Sudangrass
}

M. D. Casler

USDA-ARS, U.S. Dairy Forage Research Center, michael.casler@ars.usda.gov

Jeffrey F. Pedersen

University of Nebraska-Lincoln, jpedersen1@unl.edu

D. J. Undersander

University of Wisconsin-Madison

Follow this and additional works at: https://digitalcommons.unl.edu/agronomyfacpub

Part of the Agricultural Science Commons, Agriculture Commons, Agronomy and Crop Sciences Commons, Botany Commons, Horticulture Commons, Other Plant Sciences Commons, and the Plant Biology Commons

Casler, M. D.; Pedersen, Jeffrey F.; and Undersander, D. J., "Forage Yield and Economic Losses Associated with the Brown-Midrib Trait in Sudangrass" (2003). Agronomy \& Horticulture -- Faculty Publications. 934. https://digitalcommons.unl.edu/agronomyfacpub/934

This Article is brought to you for free and open access by the Agronomy and Horticulture Department at DigitalCommons@University of Nebraska - Lincoln. It has been accepted for inclusion in Agronomy \& Horticulture -Faculty Publications by an authorized administrator of DigitalCommons@University of Nebraska - Lincoln. 


\title{
Forage Yield and Economic Losses Associated with the Brown-Midrib Trait in Sudangrass
}

\author{
M. D. Casler,* J. F. Pedersen, and D. J. Undersander
}

\begin{abstract}
Brown-midrib genes increase digestibility due to reduced lignification in sudangrass, Sorghum bicolor subsp. drummondii (Nees ex Steud.) de Wet \& Harlan. Brown-midrib lines are known to be low in forage yield potential, but this reduction in forage yield has not been previously quantified. The objectives of this study were to quantify the increase in forage quality and decrease in forage yield and to provide an economic assessment of this dichotomy. Piper and Greenleaf (normal leaves) were compared with their brown-midrib counterparts and to four highly selected brown-midrib (FG) lines at two locations for 2 yr. Brown-midrib lines averaged 9.0\% lower in lignin and $7.2 \%$ higher in in vitro fiber digestibility than normal lines. The reduction in first-harvest forage yield was highly variable across germplasms and locations. Greenleaf and the FG lines showed severe forage yield reductions in Wisconsin but not in Nebraska, whereas forage yield of Piper was uniformly reduced across locations. Reduced tillering and plant height of the brown-midrib plants appeared to be mechanisms for reducing forage yield. The brown-midrib phenotype of sudangrass, caused by the homozygous condition of the $b m r-6$ allele, appears to be environmentally sensitive, particularly limiting production in cooler and shorter growing seasons. Conversely, uniform reductions in second-harvest forage yield suggested a fundamental limitation to regrowth potential associated with the brown-midrib phenotype. Predicted net returns from feeding sudangrass hay were similar for first-harvest normal and brown-midrib lines, but severely depressed for brown-midrib lines in second harvest, due to the severe yield reductions.
\end{abstract}

$\mathrm{B}$ ROWN-MIDRIB MUTATIONS, when present in the homozygous recessive state, result in reduced lignification, reduced cell-wall concentration, increased digestibility, and increased voluntary intake of feed by ruminants. These single-locus mutations represent the single most rapid and effective mechanism of genetically modifying nutritional value of forage crops. As singlelocus recessive mutations, they can be backcrossed readily into elite lines. Lignin concentration of brownmidrib lines has been reduced by 5 to $50 \%$; a $10 \mathrm{~g}$ $\mathrm{kg}^{-1}$ decrease in lignin generally resulted in a $40 \mathrm{~g} \mathrm{~kg}^{-1}$ increase in digestibility (Cherney et al., 1991). As a result, voluntary intake and animal performance may increase by up to $30 \%$ (Cherney et al., 1991).

Despite these advantages, and the discovery of the brown-midrib trait as early as 1931, brown-midrib mutants were not used in commercial germplasm until the 1990s. Brown-midrib phenotypes suffer from reduced vigor and yield. In maize (Zea mays L.), yield reductions

M.D. Casler, USDA-ARS, U.S. Dairy Forage Research Center, 1925 Linden Dr. West, Madison, WI 53706-1108; D.J. Undersander, Dep. of Agronomy, Univ. of Wisconsin-Madison, Madison, WI 53706-1597; J.F. Pedersen, USDA-ARS, Dep. of Agronomy, Univ. of Nebraska, Lincoln, NE 68583-0937. Received 21 Feb. 2002. *Corresponding author (mdcasler@facstaff.wisc.edu).

Published in Crop Sci. 43:782-789 (2003). associated with the brown-midrib phenotype average $\approx 20 \%$ for grain, 10 to $17 \%$ for stover, and $16 \%$ for fodder (Miller et al., 1983; Lee and Brewbaker, 1984). Some brown-midrib lines may have stover yields as high as the best normal lines, but grain yield is always depressed (Miller et al., 1983). There is one report of similar fodder yields for two pairs of isogenic brownmidrib and normal maize lines, but the brown-midrib lines were $3 \mathrm{~d}$ later in silking and had a lower ear-tostover ratio than the normal lines (Weller et al., 1985). Brown-midrib lines are generally shorter than normal counterparts, but not sufficiently so to account for all yield losses (Miller et al., 1983; Lee and Brewbaker, 1984). Brown-midrib lines have reduced stalk mass per unit length (Zuber et al., 1977) and increased stalk lodging (Miller et al., 1983). While there are no reports of yield differences between normal and brown-midrib sorghums, sudangrasses, or hybrids, the effect of bmr loci in Sorghum is generally believed to be similar to that in maize, an important impediment to commercialization (Kalton, 1988).

The objectives of this study were to quantify the increase in forage quality and decrease in forage yield associated with the brown-midrib trait in sudangrass, to determine if selection for yield and vigor can overcome the negative association between yield and quality, and to provide an economic assessment of this negative association.

\section{MATERIALS AND METHODS}

The germplasm for this study consists of two cultivars with normal leaf-blade phenotype, Piper and Greenleaf, and their brown-midrib counterparts. Piper-bmr and Greenleaf-bmr were created by three generations of backcrossing the $b m r-6$ allele from grain sorghum into Piper and Greenleaf (Fritz et al., 1981; J.D. Axtell, 1994, personal communication).

Four additional brown-midrib lines were generated from the pedigree selection and backcrossing program of the late Dr. R.R. Kalton working in collaboration with Forage Genetics, Inc., and $\mathrm{Cal} /$ West Seeds, Inc. These four lines derived from 684 lines that had been selected for vigor, disease resistance, and regrowth potential near Ames, IA, between 1965 and 1990. The 684 lines from this program were tested for initial and regrowth forage yield, establishment, and disease resistance at Arlington or West Salem, WI, between 1992 and 1995. Both self- and open-pollinated seed were produced on one to four plants per line in each year. Open-pollinated seed was used for testing, while self-pollinated seed was used to advance selected lines to the next generation.

In February 1996, seeds from Piper, Greenleaf, Piper-bmr, Greenleaf-bmr, and the best four lines from the Iowa/Wisconsin selection program (hereafter called FG lines) were germi-

Abbreviations: ADF, acid detergent fiber; ADL, acid detergent lignin; DM, dry matter; FG, Forage Genetics, Inc.; NDF, neutral detergent fiber; NDFD, neutral detergent fiber digestibility. 
nated in the greenhouse. Two hundred seedlings of each line were transplanted into isolated crossing blocks at Arlington, WI, in May 1996. Each block was isolated by a minimum distance of $200 \mathrm{~m}$ from other sorghum or sudangrass. Plant spacing was $0.9 \mathrm{~m}$ for each block. Crossing blocks were sprayed with $2.8 \mathrm{~kg}$ a.i. ha ${ }^{-1}$ alachlor [2-chloro-N-(2,6-diethylphenyl)$\mathrm{N}$-(methoxymethyl)-acetamide] and $0.07 \mathrm{~kg} \mathrm{ha}^{-1}$ imazethapyr $\{( \pm$ )-2-[4,5-dihydro-4-methyl-4-(1-methylethyl)-5-oxo- $1 H$ imidazol-2-yl]-5-ethyl-3-pyridinecarboxylic acid\} for preemergence weed control immediately before transplanting. Crossing blocks were fertilized with $100 \mathrm{~kg} \mathrm{~N} \mathrm{ha}^{-1}$ immediately after transplanting. Seed was harvested from each plant in September 1996, threshed, cleaned, and bulked in equal quantities by mass within each crossing block.

\section{Piper and Greenleaf Lines}

Two 100-seed samples of Piper, Greenleaf, Piper-bmr, and Greenleaf-bmr were tested for germination using AOSA procedures (AOSA, 1998). These four lines were planted in a double Latin square design (eight replicates total) at both Arlington, WI, and Ithaca, NE. Experiments were planted on 1 June at Arlington and 19 June at Ithaca. The soil types were Plano silt loam (fine-silty, mixed, superactive, mesic Typic Argiudolls) for Arlington and Sharpsburg silt loam (fine, smectitic, mesic Typic Argiudolls) for Ithaca. Plot size was $1.7 \times 3.0 \mathrm{~m}$ (10 drilled rows) at Arlington and $1.2 \times 3.0 \mathrm{~m}$ (seven drilled rows) at Ithaca. There were 0.9-m alleys between each tier of plots. All alleys and borders were seeded to a bulk mixture of sudangrass seed. The seeding rate was 323 pure live seeds per meter $\left(\approx 33.6 \mathrm{~kg} \mathrm{ha}^{-1}\right)$. Plots were fertilized with $100 \mathrm{~kg} \mathrm{~N} \mathrm{ha}^{-1}$ immediately after seeding. After planting, remnant seeds were stored at $-3^{\circ} \mathrm{C}$.

When most plots had reached the heads-emerged growth stage, a 0.9 - by 3.0-m swath was harvested from the center of each plot and weighed. First harvest occurred during the first week of August at Arlington and the third week of August at Ithaca. Samples of $\approx 500$ to $700 \mathrm{~g}$ were taken for dry matter (DM) determination after drying at $60^{\circ} \mathrm{C}$. Stand percentage was visually rated immediately after the first harvest, based on the percentage of linear rows that contained live tillers. Immediately after first harvest at Arlington, the number of tillers was counted on two random 1-m linear sections of row for each plot. Maximum plant height of each plot was measured immediately before each harvest. A second harvest was made after the first killing frost in autumn, using the same protocols as for the first harvest. Second harvest occurred during the last week of September at Arlington and Ithaca.

Seeds of Piper, Greenleaf, Piper-bmr, and Greenleaf-bmr were tested for germination a second time in winter 19971998 as described above. Seeding rates were recomputed on a pure live seed basis to adjust for any losses in germination. The experiment was repeated in 1998, using identical protocols as in 1997, except for the use of a single Latin square at each location in 1998 (four replicates) due to insufficient seed. The planting date was 28 May 1998 for both locations. Harvest dates were similar to those in 1997.

\section{FG Brown-Midrib Lines}

The four FG lines were planted in a separate experiment at each location in 1998 with normal Piper and Greenleaf as checks. The experimental design was a randomized complete block with two replicates and a split-plot randomization. Whole plots consisted of three subplots: one of the four FG lines plus one plot each of normal Piper and normal Greenleaf. The germination test, plot size, harvest procedures, data col- lection, and sample collection for this experiment were identical to that of the experiments described above.

\section{Laboratory, Statistical, and Economic Analyses}

Plant samples were ground through a 1-mm screen in a Wiley-type mill and scanned on a near-infrared reflectance spectrophotometer. A calibration subset of 36 samples was analyzed in duplicate for neutral detergent fiber (NDF), acid detergent fiber (ADF), and acid detergent lignin (ADL) using the procedures of Van Soest et al. (1991) with the exceptions that sodium sulfite and $\alpha$-amylase were excluded. In vitro digestibility of the NDF fraction (NDFD) was determined in triplicate (Casler, 1987; National Research Council, 2001). Values of NDF, ADF, ADL, and NDFD were predicted for all samples using a single calibration equation per variable: $\mathrm{SEC}=12.4 \mathrm{~g} \mathrm{~kg}^{-1}, R^{2}=0.89$ for NDF; $\mathrm{SEC}=11.0 \mathrm{~g} \mathrm{~kg}^{-1}$ $R^{2}=0.91$ for $\mathrm{ADF}$; $\mathrm{SEC}=4.8 \mathrm{~g} \mathrm{~kg}^{-1}, R^{2}=0.82$ for $\mathrm{ADL}$; and $\mathrm{SEC}=22.2 \mathrm{~g} \mathrm{~kg}^{-1}, R^{2}=0.83$ for NDFD.

Undersander et al. (1993) developed a method for estimating milk production per unit of forage DM as a means of combining yield and quality into a single term for comparison of treatments involving changes in both factors. For this paper, the milk production index was modified so that energy content of the forage was estimated by in vitro digestible DM rather than acid detergent fiber concentration while DM intake potential of the forage was predicted from neutral detergent fiber concentration, as described by Undersander et al. (1993). This spreadsheet (MILK95) is available at www.uwex.edu/ ces/forage.

The MILK95 spreadsheet computes the energy intake from forage for a $600-\mathrm{kg}$ milking cow consuming a diet with NDF concentration at $1.15 \%$ body weight. The cow's maintenance energy requirement, proportioned according to the percentage of forage in the diet, is then subtracted from energy intake to provide an estimate of the energy available from forage for conversion to milk (NRC, 1989). Forage DM yield multiplied times the milk produced per unit of forage DM combines forage yield and quality into a single variable, providing an estimate of the milk produced per unit land area. For purposes of calculating economic return, fixed and variable costs associated with establishment and production of sudangrass were assumed to be $\$ 765 \mathrm{ha}^{-1}$ and were charged exclusively to the first harvest. A harvest cost of $\$ 123 \mathrm{ha}^{-1}$ was charged for each harvest.

All variables were analyzed by analysis of variance, assuming replicates and years to be random effects and all other effects to be fixed. All analyses were computed separately for first and second harvests. The initial analysis included the following factors: locations, years, lines, and rows and columns (for the Latin squares) or blocks (for the randomized complete blocks). If line $\times$ environment interactions were significant, then the analyses were partitioned into subsets according to the environmental factor (separate years or locations). Comparisons of normal vs. brown-midrib lines were made using contrasts.

\section{RESULTS AND DISCUSSION}

Differences among line means were significant for nearly all variables in each year at each location and averaged across years and locations. Line $\times$ year interactions were generally not significant, so results are presented as means across years for most traits. Line $\times$ location interactions were not significant for measures of forage nutritional value, but were significant for all 
agronomic variables. These results are consistent with previously published results on normal vs. brown-midrib sorghum or sudangrass (Porter et al., 1978; Fritz et al., 1981; Hanna et al., 1981; Miller et al., 1983; Lee and Brewbaker, 1984).

\section{Forage Nutritional Value Traits}

Piper-bmr and Greenleaf-bmr were higher in all measures of forage nutritional value than their normal counterparts (Table 1). However, this effect was consistently greater for Piper than for Greenleaf, with the exception of first-harvest ADF. Across harvests, Piper-bmr and Greenleaf-bmr averaged 4.3 and 2.0\% lower NDF, 5.8 and $3.0 \%$ lower ADF, 16.3 and $8.2 \%$ lower ADL, and 8.2 and $6.1 \%$ higher NDFD than their normal counterparts.

Normal Greenleaf was consistently higher in forage nutritional value than normal Piper, averaging $4.0 \%$ lower NDF, 4.0\% lower ADF, 8.4\% lower ADL, and $7.3 \%$ higher NDFD (Table 1). The similarity of these differences to the effects of the brown-midrib locus indicate that there is considerable genetic variation for these forage nutritional value traits in normal sudangrass. This variation is likely due to quantitative trait loci (QTL) with relatively minor individual effects, compared with the brown-midrib locus. Linkage or epistatic interactions of these QTL with $b m r-6$ are probably responsible for the differential effect of the bmr-6 locus on Piper and Greenleaf.

Piper, Greenleaf, and their brown-midrib counterparts, were the subject of a series of studies, as parents of four sorghum $\times$ sudangrass hybrids with either Redlan or Redlan-bmr sorghum as the female parent (Wedig et al., 1987; Fritz et al., 1988; Wedig et al., 1988). Averaged across the studies, the brown-midrib hybrids were uniformly $14 \%$ lower in ADL (as a fraction of NDF) than the normal hybrids for both Redlan $\times$ Piper and Redlan $\times$ Greenleaf. Conversely, the brown-midrib phenotype reduced NDF concentration by $23 \%$ in

Table 1. Mean neutral detergent fiber (NDF), acid detergent fibe (ADF), and acid detergent lignin (ADL) concentrations and in vitro NDF digestibility (NDFD) for brown-midrib and normal sudangrass lines evaluated for 2 yr at Arlington, WI, and Ithaca, NE.

\begin{tabular}{|c|c|c|c|c|}
\hline Sudangrass line & NDF & ADF & ADL & NDFD \\
\hline & $-\mathbf{g ~ k g}$ & DM - & $\mathrm{g} \mathrm{kg}^{-1}$ NDF & $\mathrm{g} \mathrm{kg}^{-1} \mathrm{DM}$ \\
\hline & \multicolumn{4}{|c|}{ First harvest } \\
\hline Greenleaf-bmr & $618^{*}$ & $365^{2}$ & $61.1^{* *}$ & $\mathbf{5 1 3} * *$ \\
\hline Greenleaf-normal & 634 & 377 & 66.7 & 481 \\
\hline $\begin{array}{l}\text { Piper-bmr } \\
\end{array}$ & 642** & 385 & $63.6^{* * *}$ & $492 * *$ \\
\hline Piper-normal & 666 & 397 & 72.9 & 449 \\
\hline \multirow{2}{*}{ LSD0.05 } & 16 & 13 & 3.7 & 24 \\
\hline & \multicolumn{4}{|c|}{ Second harvest } \\
\hline Greenleaf-bmr & $612 *$ & $355^{*}$ & $59.3 * *$ & $\mathbf{5 4 4} * *$ \\
\hline Greenleaf-normal & 622 & 365 & 64.2 & 515 \\
\hline $\begin{array}{l}\text { Piper-bmr } \\
\end{array}$ & $610 * *$ & $347^{* *}$ & $56.2 * *$ & $\mathbf{5 4 7} * *$ \\
\hline Piper-normal & 643 & 380 & 70.0 & 479 \\
\hline LSD0.05 & 9 & 9 & 3.1 & 11 \\
\hline
\end{tabular}

* Brown-midrib line mean is significantly different from normal counterpart line mean at $P<0.05$.

*** Brown-midrib line mean is significantly different from normal counterpart line mean at $P<0.01$.

$\dagger P=\mathbf{0 . 0 7}$.

$\dashv P=\mathbf{0 . 0 8}$.
Redlan $\times$ Greenleaf and 9\% in Redlan $\times$ Piper. Differential effects of the brown-midrib allele between this study of Greenleaf and Piper lines per se and the previous studies of their hybrids with Redlan reflect genotypic background effects. While not extensively studied in Sorghum, genotypic background effects on the brownmidrib phenotype were observed for NDF and ADL of three diverse Sorghum backgrounds (Fritz et al., 1981). In particular, the sudangrass background resulted in differential effects compared with the two grain sorghum backgrounds.

The brown-midrib FG lines were generally lower in cell wall components and higher in NDFD than the two normal cultivars; these differences were frequently significant for comparisons to normal Piper, but seldom significant for comparisons to normal Greenleaf (Table 2). Taken together, the four FG lines averaged $3.7 \%$ lower NDF, 4.6\% lower ADF, 5.7\% lower ADF, and $7.6 \%$ higher NDFD than the two normal cultivars, effects that were very similar to the effects of $b m r-6$ on the Piper and Greenleaf backgrounds. These four lines were generated by $30 \mathrm{yr}$ of crossing, backcrossing, selfing, and selection for vigor and disease resistance in brown-midrib germplasm without evaluation for forage nutritional value traits. These results indicate that there has been no average loss in forage nutritional value as a result of this long-term selection program, despite the lack of direct attention paid to these traits. Nevertheless, the FG lines were variable for forage nutritional value traits, with ranges averaging $2.8,5.3,11.7$, and $5.7 \%$ of the mean for NDF, ADF, ADL, and NDFD, respectively. Thus, the potential exists for changes in forage nutritional value traits within the brown-midrib germplasm pool, either as losses in forage nutritional value by ignoring these traits or increases in forage nutritional value by selecting for these traits (Casler, 2001).

\section{Ground Cover, Tiller Number, and Plant Height}

Normal Piper and Greenleaf averaged 89 to $100 \%$ ground cover and 57 to 77 tillers $\mathrm{m}^{-1}$ across years and locations and did not differ from each other for these two traits (Table 3). Their brown-midrib counterparts had 13 to $52 \%$ reduction in ground cover and 30 to $69 \%$ reduction in tiller number at Arlington. Piper was more severely affected by the $b m r-6$ locus when evaluated at Arlington, with an average $44 \%$ reduction in ground cover and $67 \%$ reduction in tiller number, compared with 18 and 37\%, respectively, for Greenleaf. Ground cover was uniformly high at Ithaca with the exception of Piper-bmr in 1997, which showed a 58\% reduction in ground cover. The FG lines behaved similarly to Greenleaf-bmr at both locations in both years (Table 4). Their average ground cover was reduced by $20 \%$ at Arlington and $4 \%$ at Ithaca, compared with the two normal cultivars. They also had $43 \%$ lower mean tiller number at Arlington. The reductions in tiller number appear to explain much of the loss in ground cover associated with the brown-midrib trait at Arlington.

Part of the differences in tiller number and ground cover between normal and brown-midrib Piper and 
Table 2. Mean neutral detergent fiber (NDF), acid detergent fiber (ADF), and acid detergent lignin (ADL) concentrations and in vitro NDF digestibility (NDFD) of four brown-midrib sudangrass lines (FG) and two normal sudangrass lines evaluated at Arlington, WI, and Ithaca, NE.

\begin{tabular}{|c|c|c|c|c|}
\hline Sudangrass line & NDF & ADF & ADL & NDFD \\
\hline & 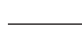 & 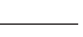 & $\mathrm{g} \mathrm{kg}^{-1}$ NDF & $\mathrm{g} \mathrm{kg}^{-1} \mathrm{DM}$ \\
\hline & & & First harvest & \\
\hline FG96-1-2 & 647 & 399 & 73.0 & 483 \\
\hline FG96-1-9 & 629 & 380 & 66.0 & 506 \\
\hline FG96-101-3 & 623 & 381 & 66.7 & 498 \\
\hline FG96-101-13 & 630 & 369 & 65.3 & 506 \\
\hline Greenleaf-normal & 644 & 389 & 69.1 & 468 \\
\hline Piper-normal & 667 & 400 & 74.4 & 441 \\
\hline Brown-midrib mean & $632 * *$ & 382* & $67.8 * *$ & $498 * *$ \\
\hline Normal mean & 655 & 394 & 71.8 & 455 \\
\hline LSD0.05 bmr lines & 22 & 32 & 7.3 & 47 \\
\hline \multirow[t]{2}{*}{ LSD0.05 bmr vs. normal } & 18 & 25 & 5.8 & 37 \\
\hline & \multicolumn{4}{|c|}{ Second harvest } \\
\hline FG96-1-2 & 632 & 379 & 73.6 & $\mathbf{5 7 0}$ \\
\hline FG96-1-9 & 640 & 380 & 79.9 & 533 \\
\hline FG96-101-3 & 638 & 387 & 77.5 & 536 \\
\hline FG96-101-13 & 628 & 376 & 70.9 & 555 \\
\hline Greenleaf-normal & 646 & 394 & 75.8 & 504 \\
\hline Piper-normal & 674 & 417 & 84.3 & 448 \\
\hline Brown-midrib mean & $634 * *$ & $380 * *$ & $75.5^{* *} *$ & $549 * *$ \\
\hline Normal mean & 660 & 405 & 80.1 & 476 \\
\hline LSD0.05 bmr lines & 13 & 20 & 7.0 & 34 \\
\hline LSD0.05 bmr vs. normal & 10 & 16 & 5.6 & 27 \\
\hline
\end{tabular}

* Brown-midrib mean different from normal mean at $P<0.05$.

** Brown-midrib mean different from normal mean at $P<0.01$.

Greenleaf was due to the limited number of backcrosses used to develop the brown-midrib sudangrass lines. Grain sorghum, with a relatively low tiller number, makes up a small part of the genome of Piper-bmr and Greenleaf-bmr, probably causing part of the tiller number reduction in the brown-midrib lines. However, differences in tiller number and ground cover response (to backcrossing the bmr-6 locus) between Piper and Greenleaf, combined with the similar tiller number and ground cover of normal Piper and Greenleaf lines, suggest interactions between $b m r-6$ and other loci. Despite their phenotypic similarity to Piper, the genetic background of Greenleaf and the FG lines appears to differ from Piper, possibly contributing to differential epistatic interactions with the bmr-6 locus.

First-harvest height of Greenleaf was unaffected by the bmr-6 locus (Table 5). However, first-harvest height of Piper and second-harvest height of both cultivars was reduced by 3.9 to $13.1 \%$ by the bmr-6 locus. The reduction in height at Ithaca was double that observed at Arlington. Similar to Greenleaf, Piper showed a greater height reduction for second harvest than for first har-

Table 3. Mean ground cover and tiller number for brown-midrib and normal sudangrass lines evaluated at two locations for $2 \mathrm{yr}$.

\begin{tabular}{|c|c|c|c|c|c|c|}
\hline \multirow[b]{3}{*}{ Sudangrass line } & \multicolumn{4}{|c|}{ Ground cover } & \multirow{2}{*}{\multicolumn{2}{|c|}{$\frac{\text { Tiller numbe }}{\text { Arlington }}$}} \\
\hline & \multicolumn{2}{|c|}{ Arlington } & \multicolumn{2}{|c|}{ Ithaca } & & \\
\hline & 1997 & 1998 & 1997 & 1998 & 1997 & 1998 \\
\hline & & & & & -1 & 1 \\
\hline Greenleaf-bmr & $\mathbf{7 3}^{* * *}$ & 83* & 99 & 95 & $48 * *$ & \\
\hline Greenleaf-normal & 93 & 95 & 91 & 100 & 69 & 57 \\
\hline Piper-bmr & $43^{* * *}$ & $60 * *$ & $40^{* * *}$ & 91 & $24 * *$ & \\
\hline Piper-normal & 89 & 95 & 96 & 100 & 77 & 66 \\
\hline LSD0.05 & 10 & 12 & 15 & 18 & 13 & 12 \\
\hline
\end{tabular}

* Brown-midrib line mean is significantly different from normal counterpart line mean at $P<0.05$.

** Brown-midrib line mean is significantly different from normal counterpart line mean at $P<0.01$. vest. Again, the FG lines behaved similarly to the Piper and Greenleaf brown-midrib lines, showing a 5.3 to $19.7 \%$ reduction in height compared with the two normal cultivars (Table 6). Because it was considerably shorter than Piper at both locations and harvests, Greenleaf was similar in height to most of the FG lines. The FG lines were variable in height, but considerably less so than Piper and Greenleaf. The reductions in plant height of brown-midrib sudangrass agree with reports of plant height of brown-midrib maize (Miller et al., 1983; Lee and Brewbaker, 1984).

\section{Forage Yield}

Forage yield of Piper was reduced by the $b m r-6$ locus uniformly across locations and harvests, by an average of $30 \%$ (Table 7). For Greenleaf, the bmr-6 locus reduced second-harvest forage yield by an average of $22 \%$, but had an inconsistent effect on first-harvest forage yield. The bmr-6 locus decreased first-harvest forage yield of Greenleaf by $15 \%$ at Arlington, but there was no

Table 4. Mean ground cover and tiller number for four brownmidrib sudangrass lines (FG) and two normal sudangrass lines evaluated at two locations in 1998.

\begin{tabular}{|c|c|c|c|}
\hline \multirow[b]{2}{*}{ Sudangrass line } & \multicolumn{2}{|c|}{ Ground cover } & \multirow{2}{*}{$\frac{\text { Tiller number }}{\text { Arlington }}$} \\
\hline & Arlington & Ithaca & \\
\hline & - & & $\mathbf{m}^{-1}$ \\
\hline FG96-1-2 & 75 & 90 & 39 \\
\hline FG96-1-9 & 83 & 90 & 48 \\
\hline FG96-101-3 & 70 & 100 & 34 \\
\hline FG96-101-13 & 73 & 100 & 41 \\
\hline Greenleaf-normal & 93 & 100 & 66 \\
\hline Piper-normal & 96 & 99 & 77 \\
\hline Brown-midrib mean & $75^{* * *}$ & $95 *$ & $41 * *$ \\
\hline Normal mean & 94 & 99 & 72 \\
\hline LSD0.05 bmr lines & 10 & 10 & 20 \\
\hline LSD0.05 bmr vs. normal & 14 & 14 & 27 \\
\hline
\end{tabular}

* Brown-midrib mean different from normal mean at $\boldsymbol{P}<0.05$.

** Brown-midrib mean different from normal mean at $\boldsymbol{P}<0.01$. 
Table 5. Mean plant height of brown-midrib and normal sudangrass lines evaluated at two locations (Arlington, WI, and Ithaca, NE) in 1997 and 1998.

\begin{tabular}{|c|c|c|c|c|}
\hline \multirow[b]{2}{*}{ Sudangrass line } & \multicolumn{2}{|c|}{ First harvest } & \multicolumn{2}{|c|}{ Second harvest } \\
\hline & Arlington & Ithaca & Arlington & Ithaca \\
\hline Greenleaf-bmr & 211 & 191 & $130 *$ & $106 *$ \\
\hline Greenleaf-normal & 213 & 194 & 139 & 122 \\
\hline Piper-bmr & $220 * *$ & $212 * *$ & $145 *$ & $123 *$ \\
\hline Piper-normal & 229 & 230 & 153 & 138 \\
\hline LSD0.05 & 5 & 6 & 8 & 14 \\
\hline
\end{tabular}

* Brown-midrib line mean is significantly different from normal counterpart line mean at $\boldsymbol{P}<0.05$.

**B Brown-midrib line mean is significantly different from normal counterpart line mean at $P<0.01$.

difference at Ithaca, effects that were consistent across years. Second-harvest forage yield of the FG lines was reduced by an average of $36 \%$, which was fairly consistent across locations (Table 8). However, first-harvest forage yield of the FG lines averaged 24\% lower than the cultivars at Arlington, but there were no differences at Ithaca. Furthermore, line FG96-101-13 showed a dramatic reversal in ranking- last at Arlington and first at Ithaca.

Without knowledge and comparative test data on the parents of the FG lines, it cannot be determined whether their $30 \mathrm{yr}$ of breeding represents a success or failure to improve forage yield in brown-midrib germplasm. However, the brown-midrib phenotype is probably responsible for the limits on forage yield observed for the FG lines in this study, for which the reductions in seasontotal forage yield, compared with normal germplasm, were approximately midway between those of Greenleafbmr and Piper-bmr. Recurrent selection for increased yield in brown-midrib maize failed to break the negative association between forage yield and quality (Barrière et al., 1988). Conversely, recurrent selection for increased stalk strength in brown-midrib maize resulted in increased stalk strength without a concomitant rise in lignin concentration (Nesticky and Huska, 1986).

The environmental instability suggests that the $b m r-6$ locus is environmentally sensitive or it may be linked to or interacting with other loci that are controlled by environmentally sensitive alleles. This linkage or epistatic effect is not operating in Piper, as indicated by

Table 6. Mean plant height of four brown-midrib sudangrass lines (FG) and two normal sudangrass lines evaluated at two locations (Arlington, WI, and Ithaca, NE) in 1998.

\begin{tabular}{|c|c|c|c|c|}
\hline \multirow[b]{2}{*}{ Sudangrass line } & \multicolumn{2}{|c|}{ First harvest } & \multicolumn{2}{|c|}{ Second harvest } \\
\hline & Arlington & Ithaca & Arlington & Ithaca \\
\hline & & & & \\
\hline FG96-1-2 & 219 & 213 & 133 & 120 \\
\hline FG96-1-9 & 218 & 200 & 141 & 118 \\
\hline FG96-101-3 & 220 & 205 & 129 & 128 \\
\hline FG96-101-13 & 208 & 213 & 138 & 105 \\
\hline Greenleaf-normal & 219 & 209 & 137 & 143 \\
\hline Piper-normal & 237 & 234 & 152 & 150 \\
\hline Brown-midrib mean & $216 *$ & $208 * *$ & $135 \dagger$ & $\mathbf{1 1 8}^{* *}$ \\
\hline Normal mean & 228 & 222 & 144 & 147 \\
\hline LSD0.05 bmr lines & 29 & 20 & 38 & 53 \\
\hline LSD0.05 bmr vs. normal & 23 & 17 & 30 & 42 \\
\hline
\end{tabular}

* Brown-midrib mean different from normal mean at $P<0.05$.

** Brown-midrib mean different from normal mean at $\boldsymbol{P}<\mathbf{0 . 0 1}$.

$\dagger P=\mathbf{0 . 1 5}$.
Table 7. Mean forage yield of brown-midrib and normal sudangrass lines evaluated at two locations (Arlington, WI, and Ithaca, NE) in 1997 and 1998.

\begin{tabular}{|c|c|c|c|c|}
\hline \multirow[b]{2}{*}{ Sudangrass line } & \multicolumn{2}{|c|}{ First harvest } & \multicolumn{2}{|c|}{ Second harvest } \\
\hline & Arlington & Ithaca & Arlington & Ithaca \\
\hline & & Mg & -1 & \\
\hline Greenleaf-bmr & 8.23** & 11.29 & $2.88 *$ & $3.63 * *$ \\
\hline Greenleaf-normal & 9.65 & 10.28 & 3.59 & 4.74 \\
\hline Piper-bmr & $7.60 * *$ & $8.21 * *$ & 2.72** & $3.91 * *$ \\
\hline Piper-normal & 11.22 & 11.23 & 4.04 & 5.50 \\
\hline LSD0.05 & 0.48 & 2.06 & 0.68 & 0.71 \\
\hline
\end{tabular}

* Brown-midrib line mean is significantly different from normal counterpart line mean at $P<0.05$.

***Brown-midrib line mean is significantly different from normal counterpart line mean at $P<0.01$.

the stable forage yield reduction in Piper across locations. For Greenleaf and the FG lines, this effect seems to be associated with the $b m r-6$ allele rather than the normal allele of this locus, as indicated by the greater phenotypic plasticity of the brown-midrib lines compared with the normal lines. Line $x$ environment interactions were entirely due to instability of the brown-midrib lines in both experiments. The difference between normal Piper and Greenleaf was highly consistent across locations, years, harvests, and experiments (11.0 to $12.5 \%$ of the mean; Tables 7 and 8).

The genotype $\times$ location interaction effects observed in Tables 7 and 8 clearly indicate an adaptive component of the brown-midrib phenotype. The results suggest that the brown-midrib phenotype in sudangrass is better adapted to the Nebraska environment than to the Wisconsin environment. This trend was evident (and fairly consistent) for Greenleaf (Table 7), for the FG lines derived from long-term selection for agronomic adaptation in Iowa and Wisconsin (Table 8), and across both years (data not shown). The brown-midrib phenotype of sudangrass appears to limit growth and development of first harvest in the cooler, shorter-season Wisconsin location. Temperature and daylength are the two most important environmental factors differing between $\mathrm{Ne}$ braska and Wisconsin locations. The enzymatic mechanism of the bmr-6 mutation is not known, but two brown-midrib mutants of maize are known to be mutants of key enzymes in the phenylpropanoid pathway for lignin synthesis (Halpin et al., 1998; Vignols et al.,

Table 8. Mean forage yield of four brown-midrib sudangrass lines (FG) and two normal sudangrass lines evaluated at two locations (Arlington, WI, and Ithaca, NE) in 1998.

\begin{tabular}{|c|c|c|c|c|}
\hline \multirow[b]{2}{*}{ Sudangrass line } & \multicolumn{2}{|c|}{ First harvest } & \multicolumn{2}{|c|}{ Second harvest } \\
\hline & Arlington & Ithaca & Arlington & Ithaca \\
\hline & & $-\mathrm{Mg}$ & $a^{-1}$ & \\
\hline FG96-1-2 & 8.56 & 10.13 & 2.92 & 3.66 \\
\hline FG96-1-9 & 8.67 & 10.44 & 2.98 & 4.50 \\
\hline FG96-101-3 & 8.84 & 10.25 & 2.76 & 4.43 \\
\hline FG96-101-13 & 6.17 & 13.86 & 2.22 & 3.42 \\
\hline Greenleaf-normal & 9.75 & 10.90 & 4.14 & 5.64 \\
\hline Piper-normal & 11.33 & 11.87 & 4.90 & 6.23 \\
\hline Brown-midrib mean & $8.06 * *$ & 11.17 & 2.72** & 4.00** \\
\hline Normal mean & 10.54 & 11.39 & 4.52 & 5.93 \\
\hline LSD0.05 bmr lines & 1.70 & 4.26 & 1.10 & 2.90 \\
\hline LSD0.05 bmr vs. normal & 1.34 & 3.36 & 0.87 & 2.29 \\
\hline
\end{tabular}

* Brown-midrib mean different from normal mean at $\boldsymbol{P}<0.05$.

** Brown-midrib mean different from normal mean at $\boldsymbol{P}<\mathbf{0 . 0 1}$. 
1995). Furthermore, severe disruptions to lignin synthesis can dramatically reduce plant vigor and health (Jung and Ni, 1998; Casler et al., 2002).

For second harvest, the effect of genotype $\times$ location interaction was relatively minor-all brown-midrib lines were more or less uniformly reduced in forage yield by 20 to $40 \%$ (Tables 7 and 8 ). This suggests that the second-harvest effect of $b m r-6$ on forage yield is not environmentally regulated and is mechanistically different than the bmr-6 effect on first-harvest forage yield. The second-harvest yield reduction may reflect a generalized reduction in vigor related to limited regrowth potential per se, rather than differential adaptation to local environmental conditions. Reduced lignification is not known to reduce regrowth per se, but there is evidence that reduced lignification can result in reduced forage yield and long-term survival of perennial forage crops (Casler et al., 2002). A significant portion of the second-harvest forage yield reduction for Greenleaf-bmr and Piperbmr may have been due to effects of residual alleles from the grain sorghum donor parent. Such an effect should be environmentally stable. However, because second-harvest forage yield of the FG lines was also significantly lower than that of Greenleaf-normal and Piper-normal, and the FG lines likely contain very little of the original grain sorghum genome, this effect probably does not explain the entire reduction in secondharvest forage yield.

\section{Predicted Milk Production and Economic Analysis}

The increased forage nutritional value of the brownmidrib lines resulted in increases in relative feed value of 7 to $23 \%$ and predicted milk production of 19 to $50 \%$ (Table 9). These effects were greatest for Piper at both harvests, as expected from the observed differences in NDF and NDFD (Table 1). Greenleaf-bmr was predicted to produce $20 \%$ higher milk yields than normal Greenleaf at first harvest. Similarly, Piper-bmr was predicted to produce $27 \%$ higher milk yields than normal Piper at second harvest. However, the effect of the $b m r-6$ locus was not significant for milk yield of first-harvest Piper or for second-harvest Greenleaf due to severe reductions in forage yield associated with the $b m r-6$ locus. For first harvest, predicted net returns were $15 \%$ and $14 \%$ greater for Greenleaf-bmr compared with normal Greenleaf per unit of forage and land, respectively. Due to forage yield depression of Greenleaf-bmr, this trend was not observed for second harvest. Both brownmidrib lines showed reduced net returns on a land area basis for second harvest.

Relative feed value and predicted milk production of the FG brown-midrib lines was significantly higher, on average, than the normal cultivars for both harvests (Table 10). The increase in predicted milk production averaged 22 and $115 \%$. Predicted milk yield of the FG lines was higher for second harvest only (35\%). For first harvest, predicted net return, per unit of hay harvested, was $15 \%$ greater for the brown-midrib lines than the normal lines. However, this advantage was not significant per unit of land due to the reduction in forage yield of the brown-midrib lines. For second harvest, results for the FG lines were similar to those for Piper-bmr and Greenleaf-bmr, showing no differences in net return on a forage basis and reduced net return for the brownmidrib lines on a land basis.

\section{CONCLUSIONS}

As shown in numerous other studies, the brown-midrib phenotype of sudangrass, conferred by the homozygous condition for the bmr-6 allele, results in stable increases in forage nutritional value. Differences between brown-midrib and normal lines are stable across locations, years, harvests, and following numerous generations of selection for increased forage yield and vigor. The brown-midrib phenotype reduced forage yield, compared with the normal phenotype, by an average of $15 \%$ for first harvest and $30 \%$ for second harvest. The reduction in forage yield was due partly to reduced ground cover, resulting from reduced tillering capability of the brown-midrib lines. The reduction in forage yield was highly stable across years, but highly unstable across locations and lines. Instability of the forage yield reduction was due to a greater phenotypic plasticity of the brown-midrib phenotype compared with the normal

Table 9. Relative feed value (RFV), milk production, and net return of brown-midrib and normal sudangrass lines evaluated over 2 yr at two locations.

\begin{tabular}{|c|c|c|c|c|c|}
\hline \multirow[b]{2}{*}{ Sudangrass line } & \multirow[b]{2}{*}{ RFV } & \multirow[b]{2}{*}{ Milk production } & \multirow[b]{2}{*}{ Milk yield } & \multicolumn{2}{|c|}{ Net return } \\
\hline & & & & Hay basis & Land basis \\
\hline & & $\mathrm{kg} \mathrm{Mg}^{-1}$ & $\operatorname{Mg~ha}^{-1}$ & $\$ \mathbf{M g}^{-1}$ & $\$ h^{-1}$ \\
\hline & & & First harvest & & \\
\hline Greenleaf-bmr & $127^{* *}$ & $942 * *$ & $9.32 * *$ & $180^{* *}$ & $1787 * *$ \\
\hline Greenleaf-normal & 118 & 761 & 7.50 & 153 & 1530 \\
\hline Piper-bmr & $116^{* * *}$ & $746^{* * *}$ & 6.11 & 129 & $1103^{* * *}$ \\
\hline Piper-normal & 105 & 513 & 5.91 & 133 & 1591 \\
\hline \multirow[t]{2}{*}{ LSD0.05 } & 2 & 34 & 0.67 & 14 & 203 \\
\hline & & & Second harvest & & \\
\hline Greenleaf-bmr & $125^{* *}$ & $1006 * *$ & 3.08 & 182 & $616^{*}$ \\
\hline Greenleaf-normal & 113 & 804 & 3.05 & 184 & 763 \\
\hline Piper-bmr & $127^{* * *}$ & $1036^{* * *}$ & $3.10 * *$ & 166 & $603^{* *}$ \\
\hline Piper-normal & 98 & 518 & 2.27 & 163 & 819 \\
\hline LSD0.05 & 5 & 79 & 0.47 & 19 & 128 \\
\hline
\end{tabular}

* Brown-midrib line mean is significantly different from normal counterpart line mean at $P<0.05$.

$* *$ Brown-midrib line mean is significantly different from normal counterpart line mean at $P<0.01$. 
Table 10. Relative feed value (RFV), milk production, and net return of four brown-midrib sudangrass lines (FG) and two normal sudangrass lines evaluated at two locations.

\begin{tabular}{|c|c|c|c|c|c|}
\hline \multirow[b]{2}{*}{ Sudangrass line } & \multirow[b]{2}{*}{ RFV } & \multirow[b]{2}{*}{ Milk production } & \multirow[b]{2}{*}{ Milk yield } & \multicolumn{2}{|c|}{ Net return } \\
\hline & & & & Hay basis & Land basis \\
\hline & & $\mathbf{k g ~ M g}^{-1}$ & $\operatorname{Mg~ha}^{-1}$ & $\$ \mathbf{M g}^{-1}$ & $\$ \mathbf{h a}^{-1}$ \\
\hline & & & First harvest & & \\
\hline FG96-1-2 & 129 & 864 & 7.96 & 131 & 1221 \\
\hline FG96-1-9 & 133 & 978 & 9.26 & 159 & 1513 \\
\hline FG96-101-3 & 134 & 982 & 9.33 & 157 & 1502 \\
\hline FG96-101-13 & 133 & 982 & 9.31 & 144 & 1534 \\
\hline Greenleaf-normal & 129 & 841 & 8.62 & 136 & 1408 \\
\hline Piper-normal & 123 & 713 & 8.25 & 120 & 1425 \\
\hline Brown-midrib mean & $132 * *$ & 951** & $8.96 * *$ & $148 * *$ & 1442 \\
\hline Normal mean & 126 & 777 & 8.43 & 128 & 1416 \\
\hline LSD0.05 bmr lines & 6 & 166 & 2.33 & 45 & 677 \\
\hline \multirow[t]{2}{*}{ LSD0.05 bmr vs. normal } & 5 & 131 & 1.84 & 36 & 536 \\
\hline & & & Second harvest & & \\
\hline FG96-1-2 & 121 & 983 & 3.23 & 192 & 646 \\
\hline FG96-1-9 & 110 & 772 & 3.02 & 177 & 709 \\
\hline FG96-101-3 & 111 & 790 & 2.89 & 168 & 659 \\
\hline FG96-101-13 & 119 & 941 & 2.59 & 153 & 458 \\
\hline Greenleaf-normal & 101 & 601 & 3.06 & 186 & 951 \\
\hline Piper-normal & 81 & 211 & 1.29 & 144 & 856 \\
\hline Brown-midrib mean & $115^{* *}$ & $871 * *$ & $2.93 *$ & 173 & 618** \\
\hline Normal mean & 91 & 406 & 2.18 & 165 & 903 \\
\hline LSD0.05 bmr lines & 10 & 204 & 1.79 & 51 & 521 \\
\hline LSD0.05 bmr vs. normal & 8 & 161 & 1.41 & 41 & 412 \\
\hline
\end{tabular}

* Brown-midrib mean different from normal mean at $P<0.05$.

** Brown-midrib mean different from normal mean at $\boldsymbol{P}<0.01$.

phenotype. However, losses in forage yield due to the brown-midrib phenotype cannot be completely attributed to pleiotropic effects of the $b m r-6$ locus. Loci controlling tillering, plant height, and forage yield are likely linked to the bmr-6 locus. Some of these loci appear to be environmentally unstable, resulting in inconsistency in the agronomic effects of the $b m r-6$ locus. The failure of long-term selection for forage yield and vigor to ameliorate these forage yield losses indicated that these linkages may be tight. Brown-midrib lines were equal to normal lines in net economic returns for first-harvest hay production. The losses in forage yield of brownmidrib lines were insufficient to offset the increased forage nutritional value. However, forage production from regrowth of these brown-midrib lines is not economically viable.

Brown-midrib phenotypes in sudangrass and/or sorghum $\times$ sudangrass hybrids could potentially produce positive economic returns compared with non-bmr genotypes. However, determination of possible linkage and/ or epistatic relationships between the $b m r-6$ locus and loci controlling adaptation and agricultural fitness will be a key component of future progress. Genotype $\times$ environment interactions will also be important as they reveal adaptive limitations to specific alleles or allele combinations.

Finally, the large amount of genetic variation for forage nutritional value traits within normal sudangrass germplasm suggests that gains in nutritional value can be made without the potential negative consequences of the brown-midrib trait. Experience from other species suggests that increases in digestibility of 1 to $2 \%$ per cycle of selection can be expected in most cases (Casler, 2001). These genetic increases in digestibility are typically a result of increasing the frequency of alleles for QTL which can be accomplished from field-grown geno- types, providing sufficient selection pressure for agronomic traits to limit or eliminate losses in forage yield (Casler, 2001). Thirty years of breeding and selection for increased digestibility in normal sudangrass germplasm probably would have resulted in germplasm with similar digestibility to the FG lines evaluated in this study, but without their potentially serious agronomic problems.

\section{ACKNOWLEDGMENTS}

We are indebted to the late Dr. John Axtell, Purdue University, for supplying seeds of the brown-midrib lines of Piper and Greenleaf. We thank Dr. Mark McCaslin, Forage Genetics Inc., for financial support and for supplying seeds of their most advanced brown-midrib lines. We thank Andrew Beal, Kim Darling, and Jon Toy for their expert assistance in field and laboratory operations of this experiment. We thank Dr. K.P. Vogel for use of seeding and harvesting equipment at Ithaca, NE.

\section{REFERENCES}

Association of Official Seed Analysts. 1998. Rules for seed testing. AOSA, Beltsville, MD.

Barrière, Y., A. Gallais, and H. Berthet. 1988. Utilisation du gène brown midrib-3 pour l'amélioration du maïs fourrage. II. Sélection récurrente de populations. Agronomie 8:625-631.

Casler, M.D. 1987. In vitro digestibility of dry matter and cell wall constituents of smooth bromegrass forage. Crop Sci. 27:931-934.

Casler, M.D. 2001. Breeding forage crops for increased nutritional value. Adv. Agron. 71:51-107.

Casler, M.D., D.R. Buxton, and K.P. Vogel. 2002. Genetic modification of lignin concentration affects fitness of perennial herbaceous plants. Theor. Appl. Genet. 104:127-131.

Cherney, J.H., D.J.R. Cherney, D.E. Akin, and J.D. Axtell. 1991. Potential of brown-midrib, low-lignin mutants for improving forage quality. Adv. Agron. 46:157-198.

Fritz, J.O., R.P. Cantrell, V.L. Lechtenberg, J.D. Axtell, and J.M. Hertel. 1981. Brown midrib mutants in sudangrass and grain sorghum. Crop Sci. 21:706-709.

Fritz, J.O., K.J. Moore, and E.H. Jaster. 1988. In situ digestion kinetics 
and ruminal turnover rates of normal and brown midrib mutant sorghum $\times$ sudangrass hays fed to nonlactating Holstein cows. J. Dairy Sci. 71:3345-3351.

Halpin, C., K. Holt, J. Chojecki, D. Oliver, B. Chabbert, B. Monties, K. Edwards, A. Barakate, and G.A. Foxon. 1998. Brown-midrib maize $(b m 1)$ - a mutation affecting the cinnamyl alcohol dehydrogenase gene. Plant J. 14:545-553.

Hanna, W.W., W.G. Monson, and T.P. Gaines. 1981. IVDMD, total sugars, and lignin measurements on normal and brown midrib (bmr) sorghums at various stages of development. Agron. J. 73:1050-1052

Jung, H.G., and W. Ni. 1998. Lignification of plant cell walls: Impact of genetic manipulation. Proc. Natl. Acad. Sci. USA 95:12742-12743.

Kalton, R.R. 1988. Overview of the forage sorghums. p. 1-12 In D. Wilkinson (ed.) Proc. 43rd Corn Sorghum Res. Conf. 8-9 Dec. 1988, Chicago, IL. Am. Seed Trade Assoc., Washington, DC.

Lee, M.H., and J.L. Brewbaker. 1984. Effects of brown midrib-3 on yields and yield components of maize. Crop Sci. 24:105-108.

Miller, J.E., J.L. Geadelmann, and G.C. Marten. 1983. Effect of the brown midrib-allele on maize silage quality and yield. Crop Sci. 23:493-496.

National Research Council. 1989. Nutrient Requirements of Dairy Cattle. 6th rev. ed. Natl. Acad, Sci., Washington, DC.

National Research Council. 2001. Nutrient Requirements of Dairy Cattle. 7th rev. ed. Natl. Acad, Sci., Washington, DC.

Nesticky, M., and J. Huska. 1986. Stalk strength in maize with brown mid-ribs. p. 107-110 In Proc. 13th Conf. EUCARPIA Maize and Sorghum Sect., "Breeding of silage maize". 9-12 Sept. 1985, Wageningen, The Netherlands.
Porter, K.S., J.D. Axtell, V.L. Lechtenberg, and V.F. Colenbrander. 1978. Phenotype, fiber concentration, and in vitro dry matter disappearance of chemically induced brown midrib $(\mathrm{bmr})$ mutants of sorghum. Crop Sci. 28:205-208.

Undersander, D.J., W.T. Howard, and R.D. Shaver. 1993. Milk per acre spreadsheet for combining yield and quality into a single term. J. Prod. Agric. 6:231-235.

Van Soest, P.J., J.B. Robertson, and B.A. Lewis. 1991. Methods for dietary fiber, neutral detergent fiber, and nonstarch polysaccarides in relation to animal nutrition. J. Dairy Sci. 74:3583-3597.

Vignols, F., J. Rigau, M.A. Torres, M. Capellades, and P. Puigdomenech. 1995. The brown midrib3 (bmr3) mutation in maize occurs in the gene encoding caffeic acid $O$-methyltransferase. Plant Cell 7:407-416.

Wedig, C.L., E.H. Jaster, and K.J. Moore. 1988. Effect of brown midrib and normal genotypes of sorghum $\times$ sudangrass on ruminal fluid and particulate rate of passage from the rumen and extent of digestion at various sites along the gastrointestinal tract in sheep. J. Anim. Sci. 66:559-565.

Wedig, C.L., E.H. Jaster, K.J. Moore, and N.R. Merchen. 1987. Rumen turnover and digestion of normal and brown midrib sorghum $x$ sudangrass hybrid silages in dairy cattle. J. Dairy Sci. 70:1220-1227.

Weller, R.E., R.H. Phipps, and A. Cooper. 1985. The effect of the brown midrib-3 gene on the maturity and yield of forage maize. Grass Forage Sci. 40:335-339.

Zuber, M.S., T.R. Colbert, and L.F. Bauman. 1977. Effect of brownmidrib-3 mutant in maize (Zea mays L.) on stalk strength. Z Pflanzenzüchtg. 79:310-314. 